\title{
Design of a Three-Finger Robot Manipulator
}

\author{
Miroslav Blatnický ${ }^{1}$, Ján Dižo ${ }^{1}$, Michal Timoščuk ${ }^{2}$ \\ ${ }^{1}$ Faculty of mechanical engeneering, University of Žilina. Univerzitná 1, 01026 Žilina. Slovak Republic. E-mail: miro- \\ slav.blatnicky@fstroj.uniza.sk,jan.dizo@fstroj.uniza.sk, \\ ${ }^{2}$ Robotec, s.r.o, Hlavná 1237/3, 03852 Sučany, Slovak Republic, E-mail: timoscuk@robotec.sk
}

The paper deals with a construction design of a versatile adaptive gripper for a robot manipulator. More specifically, it presents construction design of motional kinematics of fingers, which are controlled by a working screw, and also computation of forces and a selection of drive actuating units. Calculation of forces is needed for further correct selection of an engine transmission, considered gearing, belt gear and transmission.

Automation is a process of replacing man's control function by operation of various machines and devices. Automation is a highly complex process including very simple control operations, which are performed automatically by relatively simple devices, as well as very complex control of large production units. Control is a purposeful action of evaluation and processing of information about the controlled object or process, actions in the process (these may include measurement device data, signalling equipment states), and according to them, related machines are controlled so that the prescribed objective can be met - handling piece loads of maximal weight $m=25$ $\mathrm{kg}$ in this instance.

Keywords: Manipulator, three-finger gripper, handling machinery

\section{Acknowledgement}

The work was supported by the Scientific Grant Agency of the Ministry of Education of the Slovak Republic and the Slovak Academy of Sciences in project No. 1/0347/12: "Railway wheel tread profile wear research under the rail vehicle in operation conditions simulation on the test bench", project No. 1/0383/12: "The rail vehicle running properties research with the help of a computer simulation." and the project No. APVV-0842-11: “Equivalent railway operation load simulator on the roller rig”.

\section{References}

[1] BESEKERSKIJ, V. A. et al. (1970). Collection of automatic control tasks. (In Czech) STNL Prague. ISBN $04-$ $016-70$.

[2] BLATNICKÝ, M. (2015). Transport and handling devices - solved tasks. (In Slovak) University of Žilina. ISBN $978-80-554-1039-5$.

[3] BLATNICKÝ, M., DIŽO, J. (2015) Analytical calculation of hydraulic arm steel structure of track maintenance machine for lifting of pieses load. In: Railway Transport and Logistics. Scientific and technical on-line journal about railway transport, traffic, logistics and management. (In Slovak). Vol. XI., No. 1, 2015, Pp. 48 - 52. ISSN $1336-7943$.

[4] DIŽO, J. (2015). Evaluation of ride comfort for passengers by means of computer simulation. In: Manufacturing Technology. Vol. 15, Issue 1, 2015, Pp. 8 - 14. ISSN 1213-2489.

[5] DIŽO, J., BLATNICKÝ, M., SKOČILASOVÁ, B. (2015). Computational modelling of the rail vehicle multibody system including flexible bodies. In: Komunikacie. Vol 17, Issue 3, 2015, Pp 31-36. ISSN 1335-4205.

[6] GERLICI, J., LACK, T. (2014). Rail vehicles brake components test stand utilisation. In: Applied Mechanics and Material. Vol. 486, 2014, Pp. 379 - 386. ISSN 1660-9336.

[7] GERLICI, J., LACK, T., HARUŠINEC, J. (2013). The test stand load modulus implementation for the realistic railway operation in the laboratory conditions. In: Manufacturing Technology. Vol. 13, Issue 4, 2013, Pp. 444 449. ISSN 1213-2489.

[8] GERLICI, J., LACK, T., HARUŠINEC, J. (2014). Realistic simulation of railway operation on the RAILBCOT test stand. In: Applied Mechanics and Material. Vol. 486, 2014, Pp. 387-395. ISSN 1660-9336.

[9] KLIMENDA, F., SVOBODA, M., RYCHLÍKOVÁ, L., PETRENKO, A. (2015). Investigation of vertical vibration of a vehicle vodel driving through a horizontal curve. In: Manufacturing Technology. Vol. 15, Issue 2, 2015, Pp. 143 - 148. ISSN 1213-2489. 
[10] LACK, T., GERLICI, J. (2014). A modified strip method to speed up the tangencial stress between wheel and rail calculation. In: Applied Mechanics and Material. Vol. 486, 2014, Pp. 359-370. ISSN 1660-9336.

[11] LACK, T., GERLICI, J. (2014). A modified strip method to speed up the calculation of normal stress between wheel and rail calculation. In: Applied Mechanics and Material. Vol. 486, 2014, Pp. 371-378. ISSN 1660-9336.

[12] LACK, T., GERLICI, J. (2013). The FASTSIM method modification to speed up the calculation of tangential contact stresses between wheel and rail. In: Manufacturing Technology. Vol. 13, Issue 4, 2013, Pp. 486 - 492. ISSN 1213-2489.

[13] NANGOLO, F., SOUKUP, J. (2014). The effect of asymmetry on vertical dynamic response of railway vehicles. In: Manufacturing Technology. Vol. 14, Issue 3, 2014, Pp. 375 - 380. ISSN 1213-2489.

[14] SOUKUP, J., ŽMINDÁK, M., SKOČILAS, J., RYCHLÍKOVÁ, L. (2014). Application of mesh-free methods in transient dynamic analysis of orthotropic plates. In: Manufacturing Technology. Vol. 14, Issue 3, 2014, Pp. 441 447. ISSN 1213-2489.

[15] SVOBODA, M., SOUKUP, J. (2013). Dynamic measurement of four-axle railway wagon. In: Manufacturing Technology. Vol. 13, Issue 4, 2013, Pp. 552 - 558. ISSN 1213-2489.

[16] SVOBODA, M., SOUKUP, J. (2013). Verification of numeric solution by experiment for examination vertical oscillation of a mechanical system. In: Manufacturing Technology. Vol. 13, Issue 4, 2013, Pp. 559 - 563. ISSN 1213-2489.

[17] ŽMINDÁK, M., PELAGIĆ, Z., SOUKUP, J. (2015). Analysis of Fiber Orientation Influence to Dynamic Properties of Composite Structures. In: Manufacturing Technology. Vol. 15, Issue 3, 2015, Pp. 490 - 494. ISSN 1213 2489.

[18] www.13.boschrexroth-us.com/goto/pdf. 